\title{
Effects of a Devaluation on Trade Balance in Uganda: An ARDL Cointegration Approach
}

\author{
Godwin Kamugisha ${ }^{1} \&$ Joe Eyong Assoua ${ }^{2}$ \\ ${ }^{1}$ National Environment Management Authority, Kampala, Uganda \\ ${ }^{2}$ Faculty of Agriculture and Veterinary Medicine, University of Buea, SWR, Cameroon \\ Correspondence: Godwin Kamugisha, National Environment Management Authority. P.O. Box 22255, Kampala, \\ Plot 17/19/21 Jinja Road, Kampala, Uganda. Tel: 256-772-828-175. E-mail: godwinkamugisha@ gmail.com
}

Received: April 21, 2020

Accepted: June 1, 2020

Online Published: June 20, 2020

doi:10.5539/ijef.v12n7p42

URL: https://doi.org/10.5539/ijef.v12n7p42

\begin{abstract}
Obtaining a trade surplus, an increase in exports over imports, is a major economic indicator and one that developing economies strive to obtain. The devaluation of a country's currency is expected to be one way to obtain the trade surplus, by making imports expensive and exports cheap in the domestic country. This paper investigates the effects of a devaluation on the trade balance in Uganda in both the short run and long run. We consider two major approaches to trade balance improvement: the absorption approach and the elasticity approach. We employed an autoregressive distributed lag model (ARDL) approach to predict the long-term and short-term outcomes of a possible devaluation of Uganda's currency using gross domestic product as a proxy to income, real exchange rates and trade balances, which are the ratio of exports to imports. Our results suggest that incomes significantly affect trade balances in the long run and short run, while real exchange rates were found to only affect trade balances in the short run.
\end{abstract}

Keywords: devaluation, trade balance, ARDL, Uganda

\section{Introduction}

Uganda has seen its currency, the Ugandan Shilling (UGX), lose value in recent years. This has caused public outcry, as the prices of most products soared. With this public outcry, as well as the looming strikes, the government and major government officials argued that depreciation was good for Ugandan products. Countries may devalue their currencies with an expectation that with the weakening of the domestic currency against the trading partner's currency or foreign currencies, their exports will become cheaper in foreign countries, while imports will become expensive. This can eventually lead to increased demand for the country's exports. With this devaluation, foreign goods will become expensive to the domestic consumer which, in turn, is expected to reduce the importation of foreign goods, thus reducing foreign goods demand (Alexander, 1952). Conventional economic theory holds that following a devaluation, the trade balance will deteriorate in the short run and progressively improve as both exports and imports readjust to the time lag; a phenomenon known as the J-curve effect. With depreciation branded as 'good' for the economy, it may be implied that a devaluation is 'good'. However, how good is this devaluation to the economy? This is a typical scenario that is expected if the UGX depreciated or was devalued, making imports more expensive and exports cheaper. The Uganda Shilling was devaluated in 1987, devaluing the shilling by 76 percent as a disincentive for imports. From mid to late 1980s, the UGX exchanged with the USD at a rate of 7.3 Ush to USD1. In 1981, the then Government of Uganda (GoU) floated the currency in 1981 and saw its value drop to 78 Ush to USD1. A two-tier exchange rate, where all current account transactions take place at a pegged commercial rate, while capital account transactions occur in a free/floating system, was introduced in 1982. This was primarily introduced in an effort to prevent the country from large capital movements. The two-tier system was, however, abolished. In its place was a uniform rate that was established at 299 Ush to USD1 in 1984. Since the 1990s, the UGX has been generally stable and fluctuating against the market mechanisms.

The various epochs of devaluation in Uganda since 1987 has been a subject of scholarly debate on the short run and long run effects of devaluation on the trade balance. To the best of our knowledge, the literature on this issue is still deficient both empirically and analytically for Uganda. The main goal of this paper is to estimate the effectiveness of a devaluation on the trade balance in Uganda, that has experienced three rounds of devaluation 
since 1987. Specifically, the paper seeks to establish whether devaluation improves the trade balance and establish the effect of income on the trade balance. The remainder of the paper is structured as follows: the next section of the paper, we present a brief overview of Uganda's economy. The empirical and theoretical literature related to devaluation is presented in section 3, with focus on developing economies. In section 4, we present the materials and methods, which includes the model specification and some theoretical considerations. The empirical results and discussion are presented in section 5, and in section six we present the conclusion and draw some policy implications.

\section{Brief Overview of Uganda's Economy}

Like many other sub-Saharan African (SSA) countries, Uganda relies heavily on the exploitation of its natural resources and agricultural land to achieve its economic growth and development objectives. Its current GDP per capita (current prices) stands at USD671 with the average headline and core inflation at $2.8 \%$ and $2.4 \%$ respectively. Maintenance of a single digit inflation figure is majorly attributed to a balance in prices of food items. Since independence (1962), Uganda's economic growth has been very modest. Annual average growth rate stands at $4.5 \%$ and is expected to rise to 6 percent in 2019. This is expected to be driven by an increase in foreign direct investment and the increased investment in the oil and gas sector. According to Uganda's Economic Outlook in 2018, Deposit rate dropped from 12.1 percent in December 2016 to 8.6 percent in November 2017. There was also increase in domestic borrowing by the government from 2,258.6 billion shillings in December 2016 to 3,089.4 billion in November 2017. Despite all these, the Business Tendency Indicator moved up to 58.8 in December 2017 from 54.4 registered a year ago while the Composite Index of Economic Activity edged up from 195.8 to 206.7 during the same period. Uganda experienced an increase in importation of raw materials and capital goods, registering growth of $17.4 \%$ in the calendar year 2017 declining from $21.1 \%$ in 2016. According to the revised National Household Survey Report published by the Uganda Bureau of Statistics (UBOS) in February 2018, the proportion of people living in poverty now stands at 8 million. This implies that $21.4 \%$ of Ugandans are living in poverty. Real GDP was expected to grow by $5.5 \%$ in 2018 and then accelerate to between 5\% and 7\% per year, during the period 2018 to 2022. However, despite the projected recovery in growth of the economy, wealth levels measured by GDP per capita were expected to remain below the magic number of USD1,026 that is required to attain middle income status.

Figure 1 shows a pattern of nominal exchange rates from January 1992 to June 2012. Since the beginning of the second half of 2008, nominal exchange rates in Uganda increased as the Ugandan Shilling (UGX) depreciated sharply against the United States Dollar (USD). This brought about public outcry, as imports became more expensive. The GoU, however, insisted that this was good for the economy, as depreciation of the UGX would consequently render domestic goods to be cheaper to foreign trading partners, increasing exports and the market for domestic goods.

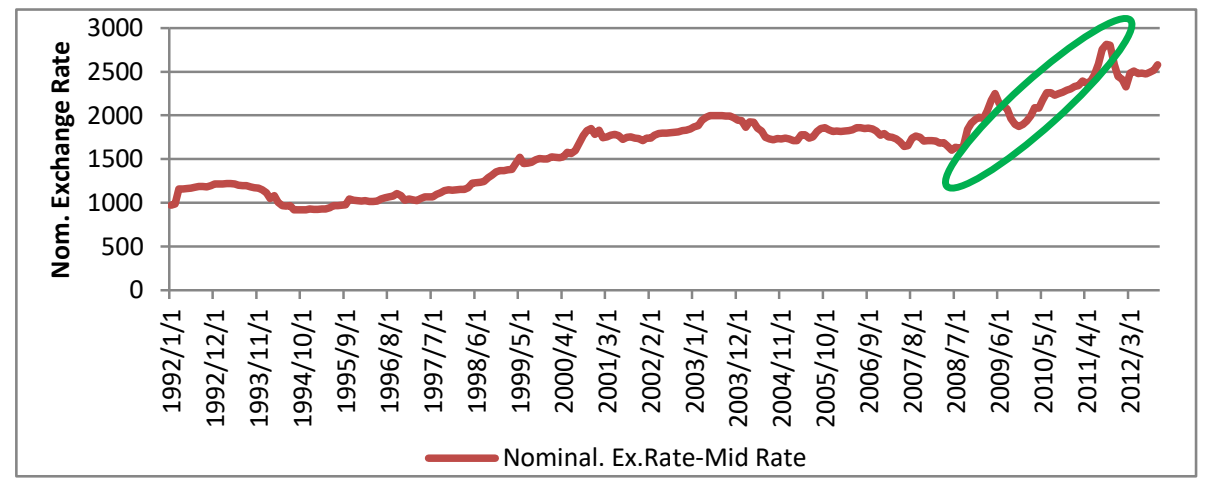

Figure 1. Monthly official midrate nominal exchange rates for the Ush to USD, 1992-2012

Source: Bank of Uganda.

Figure 2 illustrates the performance of exports and imports over the period of March 2008 to December 2012, when the UGX depreciated sharply (see Figure 1). The results illustrate that the depreciation had no significant impact on exports or imports. The question to ask then becomes: would such a trend take place if devaluation was to occur? It is also worth noting that with imports becoming more expensive, a larger budget deficit would likely arise in an economy, which relies to a significant extent, on international trade taxes to fund its budget. This is because most business activities are in the informal sector and not in the tax net. 


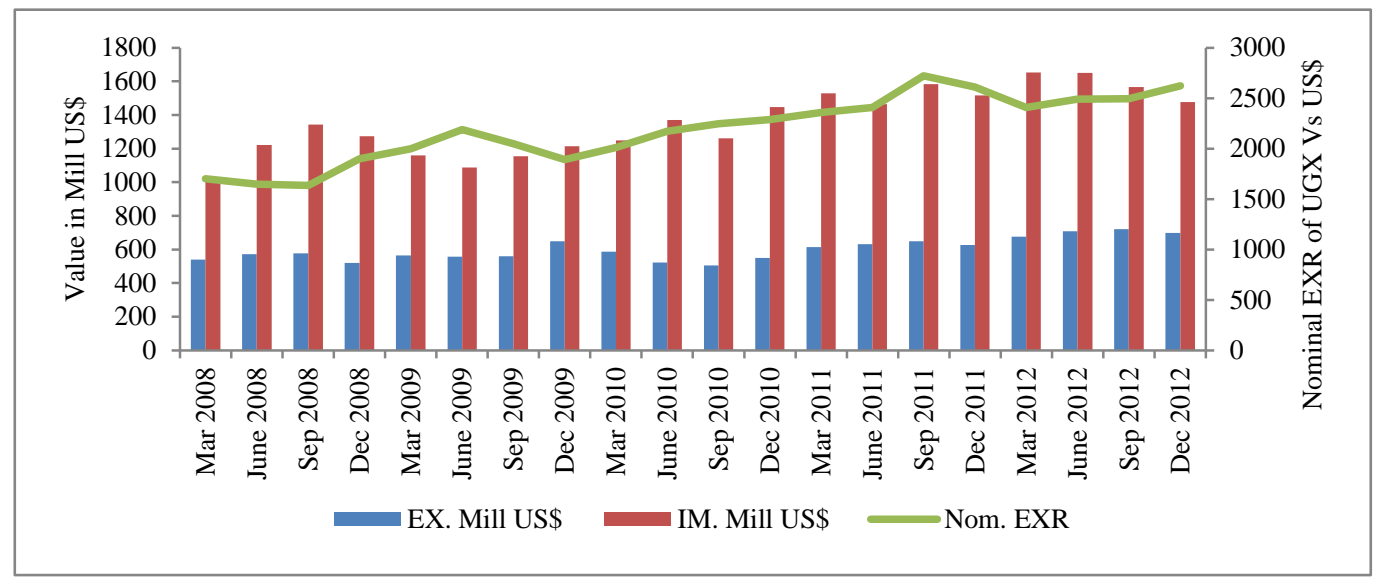

Figure 2. Quarterly exchange rate, value of imports and exports in USD. March 2008 - Dec 2012

Source: Bank of Uganda.

Figure 3 illustrates the average monthly prices in UGX of petrol/gasoline and diesel, as well as the consumer price index (CPI) compared with the official monthly exchange rates between the period of January 2005 and June 2012. The graph reveals that the fuel pump prices trace an approximate pattern with the exchange rates, especially after January 2009. An increase in exchange rates, which implies the depreciation of the Ush, is accompanied by an increase in oil pump prices.

The CPI, an indicator of the price level of goods, follows a consistent pattern in Figure 3, showing an increase in the prices of goods. The larger the level of increase in petroleum product pump prices and the exchange rate, the more the prices of the goods increase, ceteris paribus.

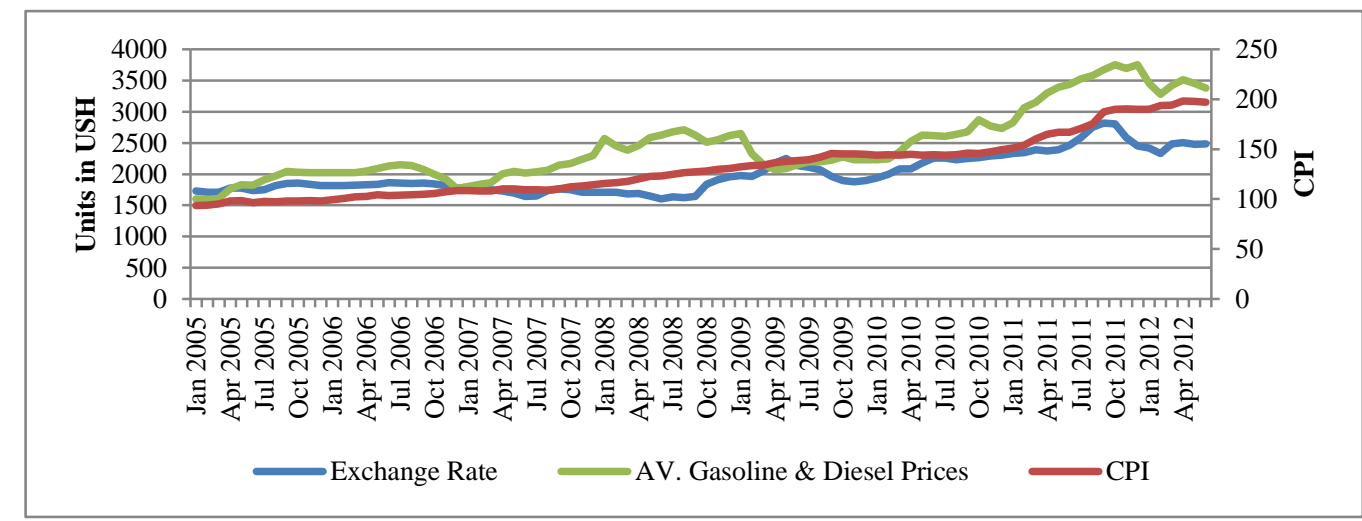

Figure 3. Relationship between exchange rates, average petroleum product prices and the consumer price index (CPI) Data

Source: Bank of Uganda.

Between April 2011 and October 2011, a large increase in the exchange rates and an increase in the pump prices is observed; i.e. an 18 percent increase in the exchange rate, a 14 percent increase in pump oil prices, and a 15 percent increase in commodity prices during the same time period. All Ugandan oil is currently imported: approximately 85 percent come through Kenya and the balance of 15 percent comes through Tanzania. As such, an increase in the exchange rates will lead to an increase in the oil pump prices, and consequently, an increase in commodity prices. This increases the cost of living of the local Ugandan, as the real value of their income decreases. Tsiang (1961) posits that the aggregate impact of a devaluation on an economy has to be assessed comprehensively, by considering the changes in outputs, incomes and prices. Therefore, this paper considers a holistic approach, where the elasticity and absorption approaches are both considered, to assess the long run effect of devaluation of the UGX on the Ugandan economy. 


\section{Related Literature}

The effects of a devaluation on the trade balance has perhaps remained a controversial issue within the international trade literature over time (Brown, 1942; Arnold, 1950; Kennedy, 1951; Miles, 1979; Turnovsky, 1980; Bahmani-Oskooee, 1985; Backus et al., 1994; Arize et al., 2000; Win Lin \& Chi-Chur, 2000; Barkoulasa et al., 2002; Stučka, 2004; Kim \& Ying, 2007; Muhammad \& Kashif, 2011; Prakash \& Maiti, 2016). As such, some critical questions have been raised: Do devaluations improve or actually worsens the trade balance? Can such scenario be true or applicable to developing economies such as Uganda? These questions and more have been at the centre of trade policy debates in academic and policy circles. The international trade literature estimating the effects of devaluation on the trade balance has evolved since the 1930's using a plethora of approaches that has generated mixed results (Alexander, 1959; Michaely, 1960; Negishi, 1968; Kakar et al., 2010; Arize et al., 2017). Robinson's seminal paper "Essays in the Theory of Unemployment" is given much credit in terms of devaluation theory. The premise of Robinson (1937) was based on three major questions: (1) If devaluation would effectively improve domestic trade balances, (2) If there are effects of devaluation on domestic output and employment, and (3) If better terms of trade implied better welfare conditions. Marshall and Lerner used the elasticity approach to assess changes in trade balances due to a change in the relative prices of domestic and foreign goods occurring from a devaluation. Like Robinson, Alexander (1952) used the absorption approach to interpret how a devaluation affects income, how a change in income level affects absorption and how a devaluation affects absorption, given any level of income. Until recently, the dominant school of thought was that devaluation is expected to improve the trade balance in the long run; however, in the short run, the trade balance first declines and later improve. Recent studies however have found that devaluation may not necessarily improve the trade balance in the long run. Upadhyaya and Dhakal (1997) estimated the effectiveness of devaluation on the trade balance in eight developing countries from Latin America, Africa, Europe, and Asia and found that with the exception of Mexico, devaluation does not improve the trade balance in the long run. Wilson and Esmond (2014), in studying selected Caribbean countries realised that there exist changes in the balances of trade for the countries under study, and these occur in both the short and the long runs, yet not all satisfy the ML-condition in the short run. In the short run, the currency depreciation is taken to almost definitely lead to an improvement in trade balances which is not sustainable in the long run. The study suggests major structural adjustments for the improvement of trade balances in the long run.

In studying over 63 developing countries, Schröder (2013) suggests that, devaluation is not enough to guarantee economic growth, exchange rate, should be consistent with the necessary macro-economic infrastructure from within and from out, for example there should be a steady supply to markets. Bleaney and Saxena (2018) examine the susceptibility to growth collapses under different exchange rate regimes. Where a country finds it important to do a peg, they have proved that devalued pegs are less susceptible to growth collapses compared to pegs that have not been devalued. This is however against the background that flexible exchange rates absorb shocks due to internal price rigidities. Genemo (2017) in studying the effect of exchange rate on trade balances in selected African countries, explains that some countries, like Egypt and Kenya would realise a worse-off terms of trade with a currency depreciation while countries like Rwanda and Tanzania, would on the other hand realize a better term of trade with a currency depreciation. The worse-off trade balances could arise due to increase in importation of goods and services for both private and public purposes. He confirms, that a depreciation of the real exchange rate also depreciated trade balances in the long run. Availability of macro-economic infrastructure, like steady export market, would however ensure a healthy trade balance in the long run.

In their study to understand the effect of exchange rate volatility on trade flows in SSA countries, Musila and Al-Zyoud (2012), it was established that the fluctuations in exchange rate to an extent reduce the level of international trade. The elasticities are however small indicating that the overall impact of such volatilities on international trade and thus terms of trade will be low. Yiheyis (2006) in his study on how aggregate output is affected by devaluation, the contractionary devaluation hypothesis tested in pooled data from over 20 African countries, found out that devaluation is contractionary in the short run and temporary. It also further identifies that a devaluation exerted little effect on the total output of a country. It is worth noting that in a situation where there are low export and import price elasticities, trade balances are bound to decline, which may, in turn, lead to a recession (Acharya, 2010). San et al. (2000) employed a computable general equilibrium (CGE) models, a national model, and a regional model of Sumatera, with focus on agriculture to investigate the effect of a devaluation on the Sumatera region. They found that a devaluation led to a reduction in imports and an increase in regional exports. However, the increase in exports was in the non-agricultural sector. With unemployed resources, devaluation is expected to affect incomes and lead to an increase in exports of a country, inducing 
domestic demand through multiplier relationships. Acharya (2010), in studying the possible impacts of devaluing the Nepalese currency, found that, in the short run, devaluation increases exports and reduces imports in the Nepalese economy. He also found that both agricultural and industrial activities expand, while service activities contract. Agricultural activities may expand because of the agro-based nature of the Nepalese industries. He argues that an increase in both agriculture and industry imply factor movements from the services sector. With a much larger devaluation, factor movements would be realized from agriculture to industrial areas, which may, consequently, lead to a contraction in agricultural services. Acharya also stated that devaluation increases the budget deficit and increases the income gap between the poor and the rich. Lai et al. (2000) found that devaluation leads to reduced unemployment, as labour unions will concentrate on increasing the wages of their members, given the fall of the real value of current wages, as a result of devaluation. By this, labour unions tend to neglect membership employment. Uganda, with its extremely weak labour unions, a devaluation will lead to both reduced real wages and employment levels. Devaluation affects absorption. As such, with imports becoming expensive, domestic demand will tend to increase. This may increase the domestic price level, narrowing the price difference between foreign market prices and domestic market prices. Developing countries, like Uganda, will have a challenge on the elasticity of supply of import substitutes and the level at which the country's goods are substitutable to imports.

\subsection{Theoretical Review of the Marshall-Lerner (ML) Condition}

\section{The ML Equation:}

For traded goods, the domestic goods price $\left(\mathrm{P}_{\mathrm{x}}\right)$ is invoiced in domestic currency. The foreign goods price $\left(P_{m}^{*}\right)$ is invoiced in foreign currency, assuming that the price elasticity of supply is infinite in both domestic and foreign countries and that supply is totally determined by demand.

An equation representing the domestic country's trade balance, in terms of the foreign country's currency, is:

$$
\begin{aligned}
& T B=P_{x}^{*} X-P_{m}^{*} M \\
& T B=\left(\frac{P_{x}}{E}\right) X-P_{m}^{*} \cdot M \\
& =\left(\frac{P_{x}}{E}\right) \cdot\left[X\left(\frac{P_{x}}{E}\right)\right]-P_{m}^{*} \cdot\left[M\left(E \cdot P_{m}^{*}\right)\right] .
\end{aligned}
$$

Where TB represents the Trade Balance; $\mathrm{E}$ is the nominal exchange rate of the domestic country vis-a-vis the foreign country, $\mathrm{M}$ is imports and $\mathrm{X}$ represents exports.

The element $\left[X\left(\frac{P_{x}}{E}\right)\right]$ shows that the domestic country's export demand is a function of its export price in the foreign currency. The element $\left[M\left(E . P_{m}^{*}\right)\right]$ illustrates that the domestic country's import demand is a function of the import price in its own currency.

If it is assumed that $P_{m}^{*}=P_{x}^{*}=1$, then:

$$
\begin{aligned}
& T B=X(E)-E \cdot M(E) \\
& \text { Differenci ating, }(W R T) E \\
& \frac{\partial T B}{\partial E}=\frac{\partial X}{\partial E}-E \frac{\partial M}{\partial E}-M
\end{aligned}
$$

For trade balances to improve, $\frac{\partial \mathrm{TB}}{\partial E}>0$. Dividing through by $\mathrm{M}$ :

$$
\left[\frac{\partial X}{\partial E} \cdot \frac{1}{M} \cdot \frac{E}{X} \cdot \frac{X}{E}\right]-\left[\frac{E}{M} \cdot \frac{\partial M}{\partial E}\right]-\frac{M}{M}>0
$$

I then define $\epsilon_{m}=-\left(\frac{\partial M}{\partial E}\right)\left(\frac{E}{M}\right)$ as the home import demand elasticity and $\epsilon_{x}=\left(\frac{\partial X}{\partial E}\right)\left(\frac{E}{X}\right)$ as the foreign demand elasticity for the domestic country's exports. Therefore:

$$
\begin{gathered}
\epsilon_{x}\left(\frac{1}{M} \cdot \frac{X}{E}\right)+\epsilon_{m}>1 \\
\Rightarrow \epsilon_{x}+\epsilon_{m}>1
\end{gathered}
$$

since $E M=X=1$ if trade is balanced. 
Equation 2 is the ML condition that the sum of the elasticities has to be greater than unity for a devaluation to improve a country's trade balances.

\section{Materials and Methods}

\subsection{Model Specification and Theoretical Considerations}

The Autoregressive Distributed Lag Model (ARDL) approach to cointegration, as propounded by Pesaran and Shin (1995), Pesaran and Shin (1998), Pesaran et al. (2001), was used to evaluate the long run and short run relationships between trade balances, the exchange rate and income. This model has a variety of advantages over the traditional Johansen and Juselius (1990) model approach. The first is that the latter uses a system of equations to predict the long run relationships, while the former utilizes a single reduced form equation. In addition, with the ARDL, the pretesting of variables is not necessary; thus, testing relationships between variables in levels is applicable, whether the independent variables are $\mathrm{I}(0), \mathrm{I}(1)$ or both (Arize, 1996). The ARDL approach to cointegration avoids many specifications made in traditional approaches, including the number of endogenous and exogenous variables to be included and the optimal number of lags to be specified. With the ARDL cointegration test, different variables can have differing lag lengths. This model is also not sensitive to nuisance parameters in a finite sample; thus, making it small sample superior.

In this paper, the dependent variable (trade balance) will be used as the ratio of exports to imports. Traditionally, trade balance would be exports less imports, but that would mean it could not be interpreted for both nominal and real terms. The real exchange rate will be used to capture the element of elasticity, while GDP will be used as a proxy to income to capture the element of absorption.

The model to be estimated will take the following form:

$$
\begin{aligned}
& \Delta \ln (T B)_{t}=\beta_{0}+\sum_{i=1}^{n} \phi_{i} \Delta \ln (T B)_{t-i}+\sum_{i=0}^{n} \theta_{i} \Delta \ln (G D P)_{t-i}+\sum_{i=0}^{n} \delta_{i} \Delta \ln (R E R)_{t-i}+\alpha_{1} \ln (T B)_{t-1} \\
& +\alpha_{2} \ln (G D P)_{t-1}+\alpha_{3} \ln (R E R)_{t-1}+\varepsilon_{i}
\end{aligned}
$$

Where TB represents trade balances (ratio of exports to imports), GDP is the Gross Domestic Product, RER is the Real Exchange Rate and the $\Delta$ operator represents the first difference. The parameters $\phi_{i}, \theta_{i}$ and $\delta_{i}$ represent the short run occurrences of the model, while $\alpha_{1}, \alpha_{2}, \alpha_{3}$ show the long run relationship of the model. The dependent variable is regressed against itself to account for the sluggish adjustment process that may result as a result of the trade balance response to the changes in regressors.

The model tests the hypothesis:

$$
\begin{aligned}
& H_{0}: \alpha_{1}=\alpha_{2}=\alpha_{3}=0 \\
& H_{a}: \alpha_{1} \neq \alpha_{2} \neq \alpha_{3} \neq 0
\end{aligned}
$$

As illustrated by Pesaran (1997) and Peseran et al., (2001) and further utilised by Kakar et al. (2010) and Duasa (2007), a bounds test for the hypothesis will be conducted for no cointegration. The F-statistic will be compared with the critical values, as computed by Pesaran and Shin (2001). If the F - statistic exceeds the respective upper critical values, a long run relationship exists. If the test statistic is below the upper critical value, the hypothesis will fail to be rejected. However, if it lies in the bounds, then it is inconclusive.

With evidence of a long run relationship/cointegration established, the model can be estimated as:

$$
\ln (T B)_{t}=\beta_{1}+\sum_{i=1}^{n} \phi_{2 i} \ln (T B)_{t-i}+\sum_{i=0}^{n} \theta_{2 i} \ln (G D P)_{t-i}+\sum_{i=0}^{n} \delta_{2 i} \ln (R E R)_{t-i}+\varepsilon_{i} \cdots
$$

The lag orders can be selected by the Akaike Information Criterion (AIC) or the Schwarz Bayesian Criterion (SBC) prior to estimating the model with OLS. The Error Correction Model (ECM) coefficient, $\varpi_{1}$, illustrates the rate of adjustment to the long-run equilibrium after a short-term disturbance. Consequently, the short run ECM specification equation will be:

$$
\Delta \ln (T B)_{t}=\delta_{1}+\varpi_{1}(E C M)_{t-1}+\sum_{i=1}^{n} \phi_{3 i} \Delta \ln (T B)_{t-i}+\sum_{i=0}^{n} \theta_{3 i} \Delta \ln (G D P)_{t-i}+\sum_{i=0}^{n} \delta_{3 i} \Delta \ln (R E R)_{t-i}+\varepsilon_{i} \cdot
$$

The ECM can be derived from Equation 4, such that:

$$
(E C M)_{t}=\ln (T B)_{t}-\beta_{1}-\sum_{i=1}^{n} \phi_{2 i} \ln (T B)_{t-i}-\sum_{i=0}^{n} \theta_{2 i} \ln (G D P)_{t-i}-\sum_{i=0}^{n} \delta_{2 i} \ln (R E R)_{t-i}
$$

In order to establish the goodness of fit of the model, diagnostic tests will be conducted to examine the serial correlation, normality, functional form of the model and heteroskedasticity. 


\subsection{Data Needs and Sources}

Annual data from 1982 was used. The data used in the regression model are obtained from various sources including the World Bank's World Development Indicators (WDI) database, the Ugandan Bureau of Statistics (UBOS), and the Bank of Uganda (various years).

\section{Results and Discussion}

\subsection{Long Run Regression}

After establishing that our variables are I(1), Equation 3 is run to establish the long run relationship. This is illustrated in table 1. As suggested by Pesaran et al., 2001, given that annual data has been utilised in the study, a maximum number of lags of 2 is adopted. The computed F-statistic $($ F-Statistic $=22.89)$ is found to be greater than the upper bound of the critical value of (3.87) at the 5\% level of significance by the restricted intercept and no trend. This implies that the null hypothesis, that there is no co-integration between the variables, is rejected. As such, it is determined that the availability of co-integration within the variables is confirmed at the 5\% level of confidence.

Table 1. Long run effect on trade balance

\begin{tabular}{|c|c|c|c|c|}
\hline Variable & Coefficient & Std. Error & t-Statistic & Prob. \\
\hline $\mathrm{C}$ & -1.018 & 0.224 & -4.543 & 0.000 \\
\hline$\Delta \mathrm{LNTB}_{\mathrm{t}-1}$ & 0.210 & 0.127 & 1.653 & 0.116 \\
\hline$\Delta$ LNGDP & 0.584 & 0.138 & 4.240 & 0.001 \\
\hline$\triangle$ LNRER & -0.296 & 0.154 & -1.926 & 0.070 \\
\hline$\Delta \mathrm{LNGDP}_{\mathrm{t}-1}$ & 0.141 & 0.121 & 1.168 & 0.258 \\
\hline$\Delta$ LNRER $_{\mathrm{t}-1}$ & 0.576 & 0.129 & 4.452 & 0.000 \\
\hline$\Delta \mathrm{LNTB}_{\mathrm{t}-2}$ & 0.147 & 0.120 & 1.223 & 0.237 \\
\hline$\Delta \mathrm{LNGDP}_{\mathrm{t}-2}$ & 0.820 & 0.127 & 6.443 & 0.000 \\
\hline$\Delta$ LNRER $_{\mathrm{t}-2}$ & 0.417 & 0.079 & 5.267 & 0.000 \\
\hline LNTB $_{t-1}$ & -0.806 & 0.135 & -5.983 & 0.000 \\
\hline LNGDP $_{\mathrm{t}-1}$ & 0.203 & 0.051 & 4.018 & 0.001 \\
\hline LNRER $_{\mathrm{t}-1}$ & -0.004 & 0.106 & -0.036 & 0.972 \\
\hline R-squared & 0.864 & & & \\
\hline Adjusted R-squared & 0.781 & & & \\
\hline Durbin-Watson stat & 2.782 & & & \\
\hline $\operatorname{Prob}($ F-statistic) & 0.000 & & & \\
\hline
\end{tabular}

Table 2. Wald test statistic illustrating the F-value compared with Pesaran and Shin's upper bound critical value

\begin{tabular}{|c|c|c|c|}
\hline Wald Test: & & & Upper bound critical value (3.87) \\
\hline Test Statistic & Value & df & Probability \\
\hline F-statistic & 22.894 & $(3,18)$ & 0.000 \\
\hline Chi-square & 68.681 & 3 & 0.000 \\
\hline \multicolumn{4}{|c|}{ Null Hypothesis: $C(10)=0, C(11)=0, C(12)=0$} \\
\hline \multicolumn{4}{|c|}{ Null Hypothesis Summary: } \\
\hline Normalized Restriction $(=0)$ & & Value & Std. Err. \\
\hline $\mathrm{C}(10)$ & & -0.806 & 0.135 \\
\hline $\mathrm{C}(11)$ & & 0.203 & 0.051 \\
\hline $\mathrm{C}(12)$ & & -0.004 & 0.106 \\
\hline
\end{tabular}

$\mathrm{C}(10), \mathrm{C}(11)$ and $\mathrm{C}(12)$ are the coefficients of the first lags of TB, GDP and RER, respectively.

The long run level of the effect of the independent variables on the dependent variable after normalisation is then established. The results are presented in table 3.

As shown in table 3, the level of income significantly affects the trade balance level in Uganda. A single percentage increase in income leads to a 0.68 percent increase in the trade balance. The real exchange rate effect on the trade balance is not significant; this implies that the ML condition for Uganda does not hold in the long run. Therefore, a devaluation of the UGX in a bid to improve trade balances may not be a viable way to improve trade balances. 
Table 3. Long run effect on trade balance

\begin{tabular}{|c|c|c|c|c|}
\hline Variable & Coefficient & Std. Error & t-Statistic & Prob. \\
\hline $\mathrm{C}$ & -0.673 & 0.047 & -14.453 & 0.000 \\
\hline$\Delta \mathrm{LNTB}_{\mathrm{t}-1}$ & 0.474 & 0.202 & 2.346 & 0.026 \\
\hline$\Delta \mathrm{LNGDP}_{\mathrm{t}-1}$ & 0.685 & 0.224 & 3.054 & 0.005 \\
\hline$\Delta \mathrm{LNRER}_{\mathrm{t}-1}$ & -0.071 & 0.151 & -0.467 & 0.644 \\
\hline R-squared & 0.355 & & & \\
\hline Adjusted R-squared & 0.283 & & & \\
\hline Durbin-Watson stat & 1.367 & & & \\
\hline $\operatorname{Prob}(F-$-statistic $)$ & 0.007 & & & \\
\hline
\end{tabular}

\subsection{Short Run Regression}

Table 4 illustrates the results of the short run effect of income and the exchange rate on the trade balance. It can be observed that income significantly affects trade balances in the short run in the first and second lags. The positive sign on the coefficient of income in both the first and second lags does not support the Keynesian argument: that an increase in domestic income will lead to increased demand for foreign products, thus worsening trade balances; this is a short run occurrence.

Table 4. Short run effect on trade balance

\begin{tabular}{|c|c|c|c|c|}
\hline Variable: $\Delta \mathrm{LN}$ & Coefficient & Std. Error & t-Statistic & Prob. \\
\hline $\mathrm{ECT}_{\mathrm{t}-1}$ & -0.642 & 0.136 & -4.706 & 0.000 \\
\hline$\Delta \mathrm{LNTB}_{\mathrm{t}-1}$ & 0.304 & 0.141 & 2.158 & 0.042 \\
\hline$\Delta \mathrm{LNGDP}_{\mathrm{t}-1}$ & 0.317 & 0.149 & 2.124 & 0.045 \\
\hline$\Delta \mathrm{LNRER}_{\mathrm{t}-1}$ & 0.233 & 0.1590 & 1.467 & 0.157 \\
\hline$\Delta \mathrm{LNTB}_{\mathrm{t}-2}$ & 0.156 & 0.138 & 1.130 & 0.271 \\
\hline$\Delta \mathrm{LNGDP}_{\mathrm{t}-2}$ & 0.585 & 0.168 & 3.472 & 0.002 \\
\hline$\Delta \mathrm{LNRER}_{\mathrm{t}-2}$ & 0.390 & 0.105 & 3.720 & 0.001 \\
\hline Constant & -0.101 & 0.033 & -3.067 & 0.006 \\
\hline R-squared & 0.628 & & & \\
\hline Adjusted R-squared & 0.510 & & & \\
\hline Durbin-Watson stat & 2.387 & & & \\
\hline Prob(F-statistic) & 0.001 & & & \\
\hline
\end{tabular}

The real exchange rate is observed to significantly affect the trade balance in the short run, given the significance of the second lag. A depreciation / devaluation would improve trade balances, but only in the short run. The negative sign on the coefficient of the first lag of the error correction term (ECTt-1, -0.642) shows a high rate of convergence to the long run equilibrium. This implies that a deviation from the long-term equilibrium is corrected by 64.2 percent annually. A significant ECT illustrates evidence of causality in at least one direction.

Diagnostic Tests

Diagnostic tests on the ECM were then carried out to ascertain the goodness of fit of the fitted model.

\section{Test for Heteroskedasticity}

Tests are carried out using the Breusch- Pagan-Godfrey (BPG) tests:

Ho: There is no Heteroskedasticity

Ha: There is Heteroskedasticity

The null hypothesis fails to be rejected. As such, there is no heteroskedasticity, as seen by the results of the F-statistic (1.121) and Prob. F (9, 20) $=0.393$.

\section{Test for Serial Correlation}

Tests are carried out on the ECM on the null hypothesis. There is no serial correlation using the Breusch-Godfrey Serial Correlation LM test. The null hypothesis fails to be rejected. As such, there is no serial correlation with a 95 percent level of confidence with the F-Statistic (2.99) and Prob. F $(2,20)=0.07$.

\section{Normality Tests}

Normality tests are carried out on the fitted model to establish the normality of the residuals using the Jarque-Bera test against the null hypothesis stating that residuals are normally distributed. The null fails to be rejected. Hence, the residuals are normally distributed with a Jarque-Bera (1.122) and Prob (0.570). 
In order to establish the strength of the causal relationships and to evaluate the dynamic interactions among the variables, we carry out Impulse Response Functions (IRF). The IRFs show how each variable will respond to a one standard deviation shock from another variable. Therefore, by using the IRF the strength, direction and persistence of the trade balance to variations in income and real exchange rate can be determined. In simulating these IRFs, it was determined that the VAR shocks may be contemporaneously correlated. This implies that a shock in one of the variables may work through the contemporaneous correlation with shocks in other variables. Due to this contemporaneous correlation, it was determined that a reaction to a shock in another variable may not be represented adequately, as isolated shocks to individual variables cannot be identified (Duasa, 2007). This is solved by using the Cholesky factorisation, which orthogonalizes the shocks.

The ordering of the variables is then determined, since the IRFs are sometimes sensitive to the ordering, except when the correlations of the contemporaneous error terms are low. The ordering was deployed by starting with the most exogenous variable and ending with the most endogenous variable in the system (Sims, 1980). The ordering of LNRER, LNGDP, LNTB is then adopted, as illustrated in table 5, since the results indicate a high correlation between the trade balance and income and a high correlation between income and the real exchange rate.

Table 5. Contemporaneous correlations of VAR error terms

\begin{tabular}{lccc}
\hline & LNTB & LNGDP & LNRER \\
\hline LNTB & 1 & & \\
LNGDP & 0.098 & 1 & $\mathbf{1}$ \\
LNRER & $\mathbf{0 . 0 2 8}$ & $\mathbf{- 0 . 1 0 5}$ & $\mathbf{1}$ \\
\hline
\end{tabular}

Impulse response functions show a trail of the dependent variables in the VAR to shocks from all the other explanatory variables in the model. The shock in any of the dependent variables dies out to zero, implying that the developed ECM is stable. Figure 4 depicts a positive response of the trade balance to the shock in income (GDP) is observed; however, this ends after approximately 4 years. The effect of innovation on the real exchange rate on the trade balance illustrates a negative effect in year one. A positive effect is seen after two years, while the effects falls to zero before becoming negative again and before being reduced to nil again.
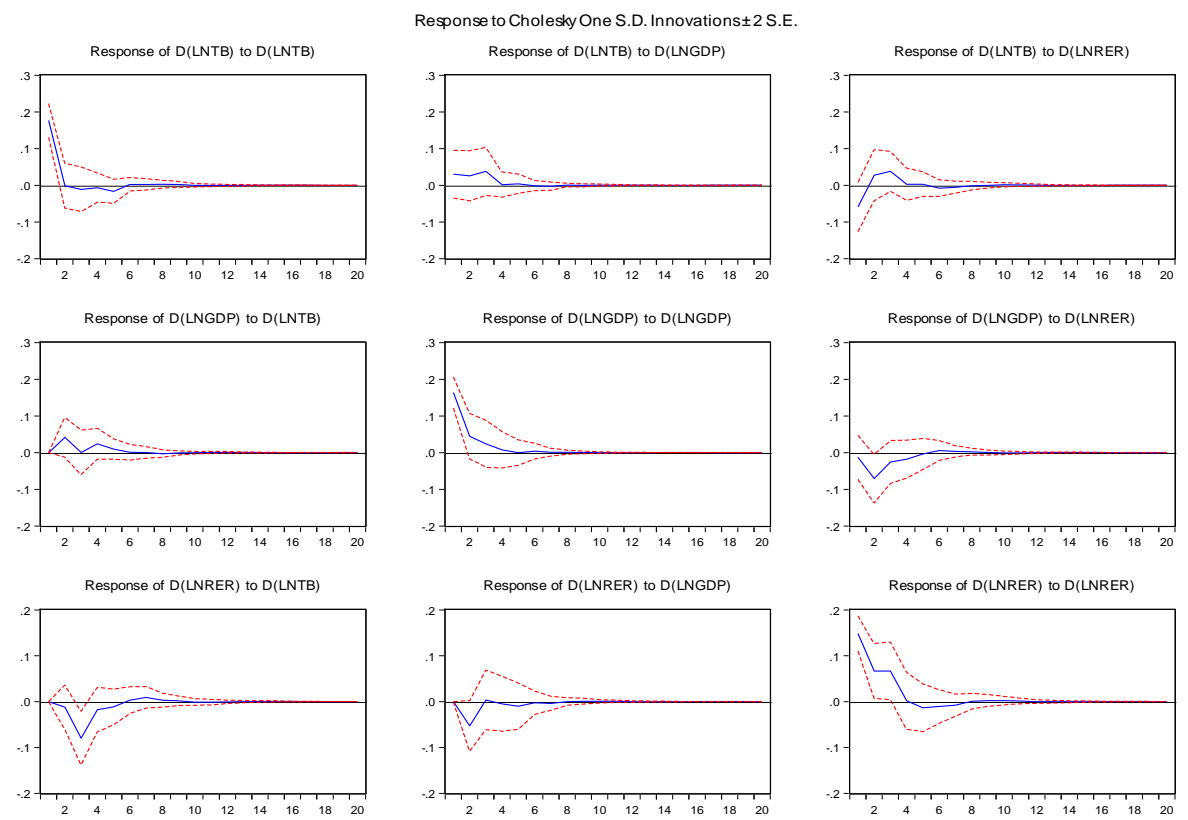

Figure 4. Impulse response function

Source: Authors' computations.

\subsection{Effect of a Devaluation on Domestic Output}

GDP was used as a proxy for income and domestic output. According to the results in table 6 , the exchange rate is found to significantly affect domestic output. An increase in the real exchange rate by 1 unit reduces the domestic output by 13 units. This implies that a devaluation negatively affects the domestic output in Uganda. 
Table 6. Effect of a devaluation on domestic output

\begin{tabular}{|c|c|c|c|c|}
\hline Variable & Coefficient & Std. Error & $\mathrm{t}$-Statistic & Prob. \\
\hline $\mathrm{C}$ & 1.894 & 0.107 & 17.653 & 0.000 \\
\hline$\Delta \mathrm{LNTB}_{\mathrm{t}-1}$ & 0.248 & 0.466 & 0.532 & 0.599 \\
\hline$\Delta \mathrm{LNGDP}_{\mathrm{t}-1}$ & 0.135 & 0.516 & 0.262 & 0.795 \\
\hline$\Delta$ LNRER $_{\mathrm{t}-1}$ & -1.135 & 0.349 & -3.254 & 0.003 \\
\hline R-squared & 0.302 & & & \\
\hline Adjusted R-squared & 0.224 & & & \\
\hline Durbin-Watson stat & 0.428 & & & \\
\hline Prob(F-statistic) & 0.020 & & & \\
\hline
\end{tabular}

\section{Conclusion and Policy Implications}

The major objective of this study was to determine to what level a devaluation would affect trade balances in Uganda by combining the elasticity and absorption approaches. The analytical method applied was a bound testing approach to cointegration using the ARDL. The model established the existence of a long run relationship between the independent variables i.e. exchange rates and income and the dependent variable trade balance, which was the ratio between exports and imports. The results show evidence of a long run relationship between the trade balance and income. More specifically, income levels were found to significantly affect trade balances. An increase in incomes would consequently lead to increased trade balances in both the long run and short run, whereas exchange rates were only found to have a significant effect on the trade balance in the short run. This implies that a devaluation may not be an appropriate approach to sustainably improve trade balances in Uganda. Therefore, the data revealed that a devaluation does not necessarily increase exports, nor reduce imports, in Uganda.

It was also determined that with an increase in the real exchange rate, a devaluation will lead to reduced domestic output in the country. This may be partly explained by the fact that a devaluation will make imports expensive; consequently, the domestic demand will increase, increasing the domestic prices of goods and lowering the price difference between the originally expensive imports and the now expensive domestically produced goods. The domestic output will not increase as expected, since the intermediate production goods are imported in Uganda and will still be imported at a high price, when compared to the price before a devaluation. This will also contribute to the hike in the domestic good prices, which will offset the positive desired effect of a devaluation. The infrastructure in Uganda may also not meet the immediate increase in demand of goods. The effect of a devaluation on the living costs of an average Ugandan can be looked at from the perspective of increases in oil prices. An increase in the effective exchange rate or a devaluation leads to an increase in oil prices, since all petroleum oil products used are imported. Since these petroleum products play a significant role in the economy and in the daily lives of every Ugandan, the increase in oil prices leads to increased domestic product prices, which increases the living costs of a normal Ugandan.

It should be noted that for the actual short run in Uganda between 2008 and 2012, with a depreciation of the Shilling, there was no significant effect in trade balances, as opposed to the findings of the model in the short run. This is likely because the model does not consider other terms necessary for improving trade balances in the short run, such as infrastructure, weather and quality seeds, among others, to meet the short run demand of domestic goods. The government of Uganda should endeavour to put into place policies that are geared towards increasing national income and/or per capita income, as well as increasing the domestic production of intermediate production goods. This may include investment in infrastructure, the modernisation of agriculture, and the facilitation of the domestic production of intermediate production inputs. The government should utilise the opportunity of new discoveries of oil to boost the export sector, since the reliability on import oil, a key element in the economy, will have to be reduced. They should then invest the generated revenue in infrastructure and various sectors of the economy that will reduce the cost of production, increase resident's incomes and boost the export sector by improving trade balances.

\section{References}

Acharya, S. (2010). Potential Impacts of the Devaluation of Nepalese Currency: A General Equilibrium Approach. Economic Systems, 34(4), 413-436. https://doi.org/10.1016/j.ecosys.2010.01.005

Alexander, S. (1952). Effects of a Devaluation on a Trade Balance. Staff papers - International Monetary Fund, 2(2), 263-278. https://doi.org/10.2307/3866218

Alexander, S. (1959). Effects of a Devaluation: A Simplified Synthesis of Elasticities and Absorption 
Approaches. The American Economic Review, 49(1), 22-42.

Arize, A. C. (1996). Cointegration Test of a Long-Run Relation Between the Trade Balance and the Terms of Trade in Sixteen Countries. North American Journal of Economics \& Finance, 7(2), 203-215. https://doi.org/10.1016/S1062-9408(96)90011-X

Arize, A. C., Malindretos, J., \& Igwe, E. U. (2017). Do exchange rate changes improve the trade balance: An asymmetric nonlinear cointegration approach. International Review of Economics \& Finance, 49, 313-326. https://doi.org/10.1016/j.iref.2017.02.007

Arize, A. C., Osang, T., \& Slottje, D. J. (2000). Exchange-Rate Volatility and Foreign Trade: Evidence from Thirteen LDC's'. Journal of Business \& Economic Statistics, 18(1), 10-17. https://doi.org/10.1080/07350015.2000.10524843

Arnold, C. H. (1950). Currency Depreciation, Income, and the Balance of Trade. Journal of Political Economy, 58(1), 47-60. https://doi.org/10.1086/256897

Backus, D. K., Kehoe, P. J., \& Kydland, F. E. (1994). Dynamics of the Trade Balance and the Terms of Trade: The J-Curve? The American Economic Review, 84(1), 84-103.

Bahmani-Oskooee, M. (1985). Devaluation and the J-Curve: Some Evidence from LDCs. The Review of Economics and Statistics, 67(3), 500-504. https://doi.org/10.2307/1925980

Barkoulasa, J. T., Baum, C. F., \& Caglayan, M. (2002). Exchange Rate Effects on the Volume and Variability of Trade Flows. Journal of International Money and Finance, 21(4), 481-496. https://doi.org/10.1016/S0261-5606(02)00003-7

Bleaney, M., Saxena, S., \& Yin, N. (2018). Exchange Rate Regimes, Devaluations and Growth Collapses. Journal of Macroeconomics. https://doi.org/10.1016/j.jmacro.2018.05.002

Brown, A. J. (1942). Trade Balances and Exchange Stability. Oxford Economic Papers, No.6 (Apr., 1942), 57-75. https://doi.org/10.1093/oxepap/os-6.1.57

Duassa, J. (2007). Determinants of Malaysian Trade Balance. An ARDL Bound Testing Approach. Journal of Economic Cooperation, 28, 21-40. https://doi.org/10.1080/12265080701217405

Genemo, K. B. (2017). Effect of Exchange Rate on Trade Balance in Major East African Countries: Evidence from Panel Cointegration. European Business and Management, 3(6), 95-104. https://doi.org/10.11648/j.ebm.20170306.11

Johansen, S., \& Juselius, K. (1990). Maximum likelihood estimation and inference on cointegration - with applications to the demand for money. Oxford Bulleting of Economics and Statistics, 52(2), 169-210. https://doi.org/10.1111/j.1468-0084.1990.mp52002003.x

Kakar, M. K., Kakar, R., \& Khan, W. (2010). The Determinants of Pakistan's Trade Balance: An ARDL Cointegration Approach. The Lahore Journal of Economics, 15(1), 1-26. https://doi.org/10.35536/lje.2010.v15.i1.a1

Kennedy, C. (1951). Devaluation and the Terms of Trade. The Review of Economic Studies, 18(1), 28-41. https://doi.org/10.2307/2296104

Kim, Y., \& Ying, Y. H. (2007). An Empirical Assessment of Currency Devaluation in East Asian Countries. Journal of International Money and Finance, 26(2), 265-283. https://doi.org/10.1016/j.jimonfin.2006.11.004

Michaely, M. (1960). Relative-Prices and Income-Absorption Approaches to Devaluation: A Partial Reconciliation. The American Economic Review, 50(1), 144-147.

Miles, M. A. (1979). The Effects of Devaluation on the Trade Balance and the Balance of Payments: Some New Results. Journal of Political Economy, 87(3), 600-620. https://doi.org/10.1086/260780

Muhammad, A., \& Kashif, K. (2011). Impact of Devaluation on Trade Balance in Pakistan. Oeconomics of Knowledge, 3(3), 16-25.

Musila, J., \& Al-Zyoud, H. (2012). Exchange Rate Volatility and International Trade Flows in sub-Saharan Africa: Empirical Evidence. Journal of African Business, 13(2), 115-122. https://doi.org/10.1080/15228916.2012.693440

Negishi, T. (1968). Approaches to the Analysis of Devaluation. International Economic Review, 9(2), 218-227. https://doi.org/10.2307/2525476 
Pesaran, H. H., \& Shin, Y. (1998). Generalized impulse response analysis in linear multivariate models. Economics Letters, 58(1), 17-29. https://doi.org/10.1016/S0165-1765(97)00214-0

Pesaran, M. H. (1997). The role of economic theory in modelling the long run. The Economic Journal, 107(440), 178-191. https://doi.org/10.1111/1468-0297.00151

Pesaran, M. H., \& Shin, Y. (1995). Long-run structural modelling. Cambridge Working Papers in Economics, 1995.

Pesaran, M. H., Shin, Y., \& Smith, R. J. (2001). Bounds Testing Approaches to the Analysis of Level Relationships. Journal of Applied Econometrics, 16, 289-326. https://doi.org/10.1002/jae.616

Prakash, K., \& Maiti, D. (2016). Does devaluation improve trade balance in small island economies? The case of Fiji. Economic Modelling, 55(2016), 382-393. https://doi.org/10.1016/j.econmod.2016.02.023

Robinson, J. (1937). Essays in the Theory of Unemployment. New York: Macmillan Co, 1937.

San, N. N., Lofgren, H., \& Robinson, S. (2000). Structural adjustment, agriculture, and deforestation in the Sumatera regional economy. International Food Policy Research Institute (IFPRI). Washington, DC, 2000.

Schröder, M. (2013). Should developing countries undervalue their currencies? Journal of Development Economics, 105, 140-151. https://doi.org/10.1016/j.jdeveco.2013.07.015

Sims, C. A. (1980). Macroeconomics and Reality. Econometrica, 48, 1-48. https://doi.org/10.2307/1912017

Stučka, T. (2004). The Effects of Exchange Rate Change on the Trade Balance in Croatia. IMF, WP/04/65, (Apr., 2004). https://doi.org/10.5089/9781451848717.001

Tsiang, S. C. (1961). The Role of Money in Trade-Balance Stability: Synthesis of the Elasticity and Absorption Approaches. The American Economic Review, 51(5), 912-936.

Turnovsky, S. J. (1980). Expectations and the Dynamics of Devaluation. The Review of Economic Studies, 47(4), 679-704. https://doi.org/10.2307/2296936

Upadhyaya, K. P., \& Dhakal, D. (1997). Devaluation and the trade balance: Estimating the long run effect. Applied Economics Letters, 4(6), 343-345. https://doi.org/10.1080/135048597355276

Wilson, S. A., \& Mclean, E. (2014). Understanding the impact of exchange rate adjustment on the Trade balance of selected Caribbean Countries. Bank of Jamaica.

Win Lin, C., \& Chi-Chur, C. (2000). Are Currency Devaluations Effective? A Panel Unit Root Test. Economics Letters, 72, 19-25. https://doi.org/10.1016/S0165-1765(01)00399-8

Yiheyis, Z. (2006). The Effects of Devaluation on Aggregate Output: Empirical Evidence from Africa. International Review of Applied Economics, 20(1), 21-45. https://doi.org/10.1080/02692170500362264

\section{Note}

Note 1. It is assumed throughout this paper that better balance of payments implies better trade balance and vice versa.

\section{Appendix}

Table 7. Unit root test

\begin{tabular}{ccc}
\hline Variable & Results at Level (Restricted Intercept \& Restricted Trend) & Results at ${ }^{\text {st }}$ Difference (Restricted Intercept \& No Trend) \\
\hline LnTB & -2.72 & $-5.59^{*}$ \\
LnGDP & $\mathbf{- 2 . 8 8}$ & $\mathbf{- 3 . 8 9 *}$ \\
LnRER & $\mathbf{- 1 . 7 8}$ & $\mathbf{- 3 . 3 7 * *}$ \\
\hline
\end{tabular}

Not assuming that the variables are of order $\mathrm{I}(0)$ or $\mathrm{I}(1)$ or both, a unit root test using the ADF technique is carried out. Note that: * and ** refer to significance at $1 \%$ and $5 \%$, respectively.

\section{Copyrights}

Copyright for this article is retained by the author(s), with first publication rights granted to the journal.

This is an open-access article distributed under the terms and conditions of the Creative Commons Attribution license (http://creativecommons.org/licenses/by/4.0/). 